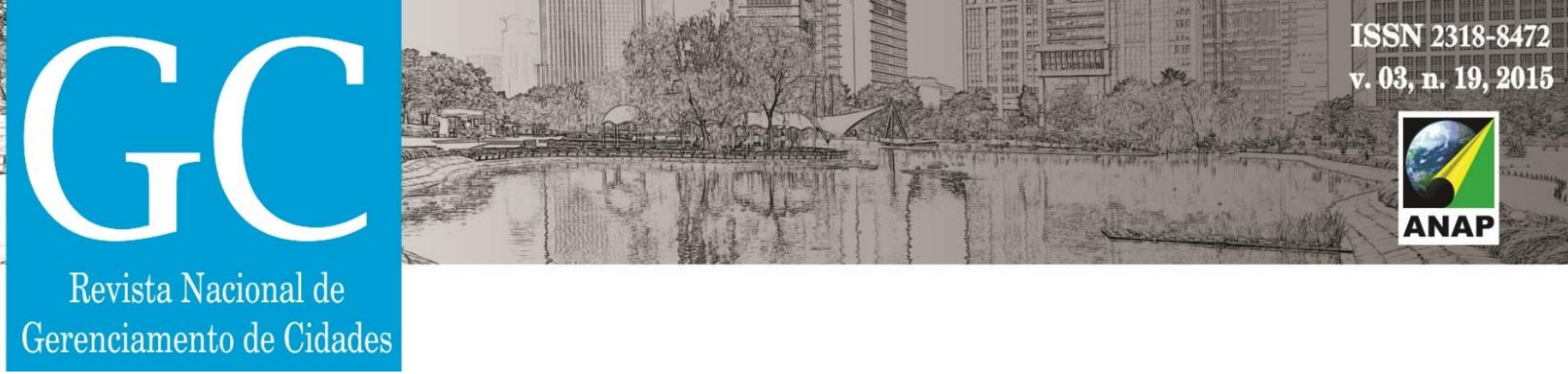

\title{
ESTUDO SOBRE TÉCNICAS COMPENSATÓRIAS DE DRENAGEM URBANA: UM ESTUDO DE CASO NA REVITALIZAÇÃO DO CÓRREGO CASCAVEL
}

\author{
Carinna Soares de Sousa ${ }^{1}$
}

Ludmila Rodrigues de Morais ${ }^{2}$

Fernanda Almeida ${ }^{3}$

\begin{abstract}
RESUMO
Este trabalho tem como objetivo descobrir o motivo da ruptura na relação entre homem e curso d'água, especificamente no córrego Cascavel em Goiânia, Goiás. Além disso, prova que é possível uma reconciliação, como defendido por Gorski (2010), através de estudos na área do Paisagismo Sustentável, Ecologia Urbana, Drenagem Urbana Sustentável e Técnicas Compensatórias de Drenagem. Foram analisados todos os cursos d'água em meio urbano na cidade de Goiânia a fim de determinar quais teriam maior influência em um meio socioeconomicamente diverso, a fim de promover a democratização do espaço público através da apropriação da APP do córrego Cascavel para este fim, e quais abrangem um maior número de problemáticas urbano-ambientais, a fim de cobrir mais amplamente as possíveis soluções para o conflito entre meio natural e cidade. Após selecionar o córrego Cascavel como estudo de caso para este trabalho, foi determinado quais programas de necessidade seriam necessários - entre o Planejamento Urbano Ecológico da área, seu Projeto Paisagístico e o Projeto de Drenagem Urbana - para a efetiva revitalização e reconhecimento da área por parte da população. Também foram realizados cálculos de prédimensionamento da capacidade de vazão de sua bacia hidrográfica, assim como o detalhamento e pré-dimensionamento das técnicas compensatórias de drenagem urbana que possibilitam, mesmo em áreas urbanas extremamente impermeabilizadas, que haja um controle eficaz sobre o excesso de vazão de águas pluviais, ou seja, que possibilite o controle de enchentes e desastres naturais.
\end{abstract}

PALAVRAS-CHAVE: Drenagem. Controle de vazão. Desenho Urbano Sensível à Água.

\footnotetext{
${ }^{1}$ Arquitetura e Urbanismo, Universidade Estadual de Goiás. carinnasousau@gmail.com

2 Arquitetura e Urbanismo, Universidade Estadual de Goiás, coordenadora. ludmorais@gmail.com

${ }^{3}$ Engenharia do Meio Ambiente. Pontifícia Universidade Católica de Goiás, professora. BASITEC, tecnóloga em Gestão Ambiental. fe.almeida09@gmail.com
} 


\title{
TECHNICAL STUDY ON URBAN DRAINAGE COUNTERVAILING: A CASE STUDY IN THE REVITALIZATION OF THE STREAM CASCAVEL
}

\begin{abstract}
This paper has the goal to discover the reason why the relationship between man and water streams has been broken, specifically in the Cascavel stream in Goiânia, Goiás. Beyond that, it proves that the reconciliation is possible, as defended by Gorski (2010), through studies based on Sustainable Landscape, Urban Ecology, Sustainable Urban Drainage and Compensatory Techniques of Urban Drainage. All urban streams in the city of Goiânia were analyzed so it could be determined which urban stream would have more influence on a socially and economically diverse urban area, in order to promote the democratization of public spaces through the society's appropriation of this stream preservation area, and which one would contain a major number of environmental urban problematics, in order to cover more widely the possible solutions for this conflict between city and natural environment. After selecting the Cascavel stream as a study case for this paper, it was proposed which requirement plans would be needed - within the Ecological Urban Planning, Landscape Project and Urban Drainage Project - so that an effective revitalization could be achieved as a true recognition from the area by the population. It has also been made pre-calculation dimensioning on the flow capacity of the basin, as the detailing and dimensioning of the compensatory techniques of urban drainage, which makes possible, even in extremely impermeable urban areas, to have an effective control on the overflow of rainwater, in other words, makes it possible to control natural disasters and floods within urban areas.
\end{abstract}

KEYWORDS: Drainage. Flow control. Water Sensitive Urban Design.

\section{ESTUDIO TÉCNICO SOBRE COMPENSATORIOS DRENAJE URBANO: UN ESTUDIO DE CASO EN LA REACTIVACIÓN DE LA SECUENCIA CASCAVEL}

\section{RESUMEN}

El estudio tiene como objetivo conocer el motivo de la terminación de la relación entre el hombre y el curso del agua, específicamente en la corriente de Cascavel en Goiânia, Goiás. Además, prueba una posible reconciliación, como se propone Gorski (2010), a través de estudios en el área de Paisaje Sustentable, Ecología Urbana, Drenaje Urbana Sostenible y Técnicas Compensatorias de Drenaje. Fueron analizados todas las corrientes en la zona urbana de la ciudad de Goiania, para determinar lo que haría más influencia de una manera socioeconómicamente diversa, con el fin de promover la democratización del espacio público a través de la apropiación de la APP de la corriente Cascavel para este fin, y que abarca un mayor número de cuestiones urbanas y ambientales con el fin de cubrir de manera más amplia posible, soluciones para el conflicto entre la naturaleza y la ciudad. Después 


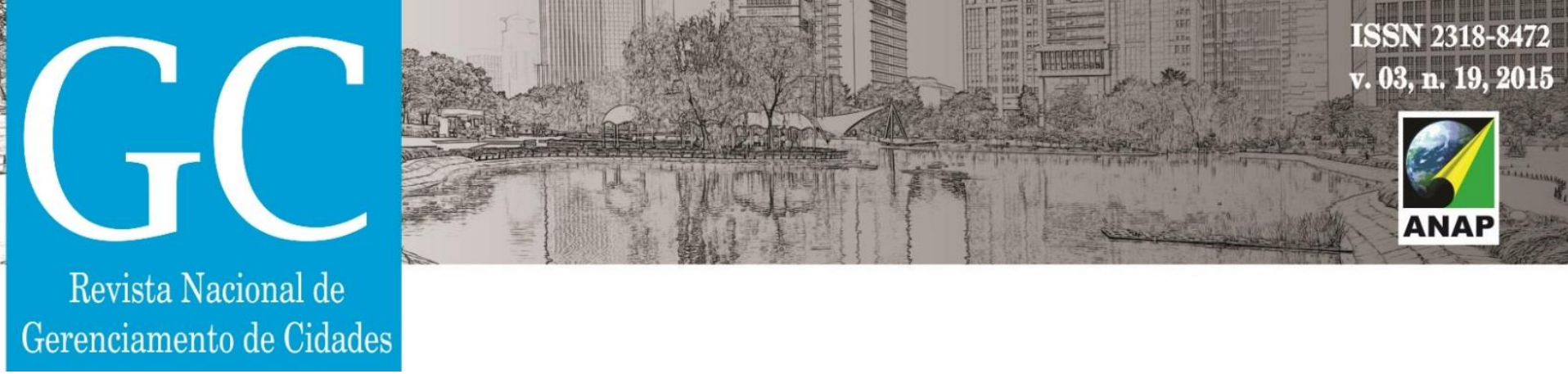

de seleccionar la corriente Cascavel como caso de estudio para este trabajo, se determinó cuales programas de necesidad serían necesarios - entre el Área de Planificación Ecológica Urbana, su Proyecto de Paisaje y el Proyecto de Drenaje Urbana - para la revitalización efectiva y el reconocimiento de la zona por la población. También se realizó cálculos preliminares de la capacidad de flujo de su cuenca hidrográfica, así como el detalle y diseño preliminar de las técnicas compensatorias de drenaje urbana que permitan, incluso en zonas urbanas muy impermeables, que hagan un control efectivo sobre el exceso de flujo de agua de la lluvia, o sea, que permite el control de las inundaciones y los desastres naturales.

PALABRAS CLAVE: Drenaje. Control de flujo. Diseño Urbano Sensible al Agua.

\title{
INTRODUÇÃO
}

\begin{abstract}
As paisagens fazem-se e desfazem-se, evoluem, ganham e perdem complexidade por ação conjugada do homem e da natureza. Nelas se ligam interativamente comportamentos físicos, químicos e biológicos. Com uma intervenção humana que, direta ou indiretamente, condiciona e interfere com o ciclo e o percurso da água, tornando-o fácil, suave, controlado e aproveitando dela o máximo como recurso essencial à vida ou, pelo contrário, acelerando-o e fazendo-o violento, caprichoso, capaz das maiores destruições (SARAIVA, 2005).
\end{abstract}

Goiânia, assim como a maioria das cidades brasileiras, se desenvolveu com uma relação crítica com seus cursos d'água. Estes, que no passado foram significados de lazer e abastecimento, passaram a ser reconhecidos pela população somente como barreiras à expansão urbana e agentes de destruição.

Após uma série de revoluções direcionadas para um Planejamento Urbano Sustentável e na Gestão Ambiental internacional, os olhares sobre os mananciais se transformaram, como é observado por Otto, McCormick e Leccese (2004 apud GORSKI, 2010, p. 77): "[...] após anos de exploração dos rios urbanos, através de uso intenso e posterior negligência, constatamos que eles são valiosos econômica e socialmente [...]".

Assim, passou-se a motivar atitudes com base sustentáveis na maneira como lidamos com a água. A busca por uma reaproximação é clara, e mudou-se o foco sobre quem é o culpado pelos desastres ambientais como enchentes e 


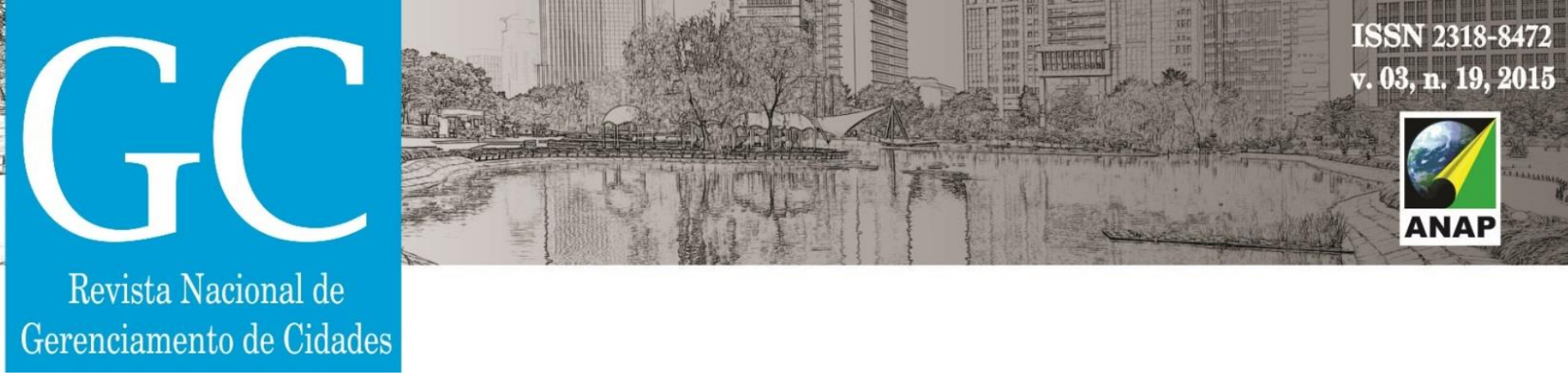

desabamentos. Hoje, entende-se que quanto mais nos aproximarmos do ciclo natural do meio ambiente, ou seja, quanto menos interferirmos nos mananciais, mais perto chegaremos de um equilíbrio ambiental.

Essa mudança de atitude se materializou em um trabalho final de graduação, base deste artigo, através da implantação de Técnicas Compensatórias de Drenagem a fim de provar que é possível implementar o conceito de Drenagem Urbana Sustentável mesmo em áreas urbanas já consolidadas, ou seja, onde o homem já interferiu em quase todo o ciclo do curso d'água deixando um índice de permeabilidade do solo quase nulo, o que dificulta o reestabelecimento do ciclo de drenagem natural da bacia hidrográfica de um determinado curso d'água.

No decorrer do trabalho foi necessário compreender questões sobre a gestão ambiental e seus diversos ramos, principalmente a gestão hídrica, entendendo como um planejamento urbano que abrange intrinsecamente 0 gerenciamento de questões ambientais traz à tona novas ferramentas para um gerenciamento urbano sustentável economicamente, socialmente e ambientalmente. Estas questões foram pertinentes para desenvolver um plano de recuperação do córrego Cascavel guiado por uma proposta de remodelação urbana baseada em diretrizes do Planejamento Urbano Sustentável, Ecologia Urbana e Drenagem Urbana Sustentável.

Estas diretrizes se concretizaram na criação de uma Infraestrutura Ecológica que tivesse como objetivos principais o controle das enchentes, controle de secas e o apoio à manutenção dos ciclos biológicos naturais (MOSTAFAVI; DOHERTY, 2010). Essa nova infraestrutura deve ser guiada por uma proposta de desenho urbano baseada nos padrões do Water Sensitive Urban Design ${ }^{2}$ e através de Técnicas Compensatórias de Drenagem Urbana, que têm como objetivo desenvolver o desenho urbano com elementos sensíveis ao comportamento hídrico da bacia de

\footnotetext{
${ }^{2}$ Water Sensitive Urban Design²: Em tradução literal, Design Urbano Sensível à Água. Conceito utilizado na revitalização de áreas portuárias como Portland em Melbourne, Austrália e demais cidades que procuram desenhar seu espaço urbano de forma sensível ao ciclo hidrológico natural de seus mananciais.
} 


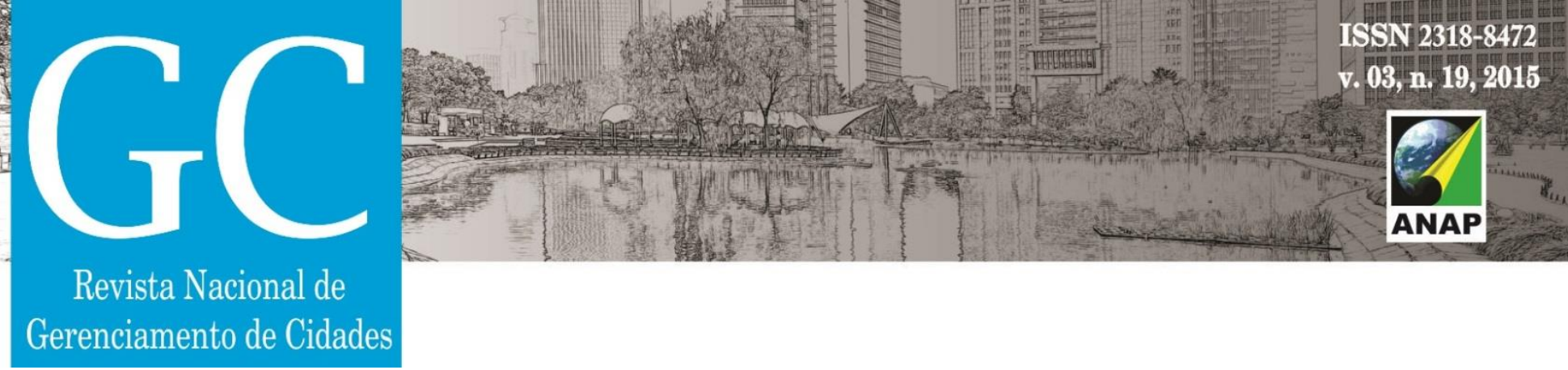

determinado curso hídrico e que possam, tecnicamente, suprir, através da remodelação do desenho urbano, as necessidades exatas dos cálculos de vazão, volume e permeabilidade que a bacia do córrego Cascavel necessita para obter seu equilíbrio ecológico.

\section{OBJETIVOS}

O trabalho base deste artigo partiu de uma série de pesquisas e se concentrou na busca pela compreensão dos ciclos naturais e as consequências das ações humanas no mesmo. O objetivo inicial era encontrar o porquê, na maioria das capitais brasileiras, esta relação entre meio urbano e água se tornou tão prejudicial a ambos homem e natureza.

O objetivo seguinte era descobrir como esta realidade poderia ser revertida, apoiado na ideia central de que a qualidade de vida urbana encontra seu ápice somente quando este relacionamento entre cidade e meio ambiente é reestabelecido de maneira saudável e equilibrada.

\section{METODOLOGIA}

\section{A ESCOLHA DO CURSO D'ÁGUA}

Para desenvolver a pesquisa foi necessário escolher um curso d’água na cidade de

Goiânia onde se concentrasse um maior número de problemáticas, a fim de gerar um estudo que abrangesse o máximo de soluções socioambientais possíveis e que tivesse influência sobre um maior número de ocupações urbanas com situações socioeconômicas diversas. Assim, pretende-se transformar o atual quadro de 


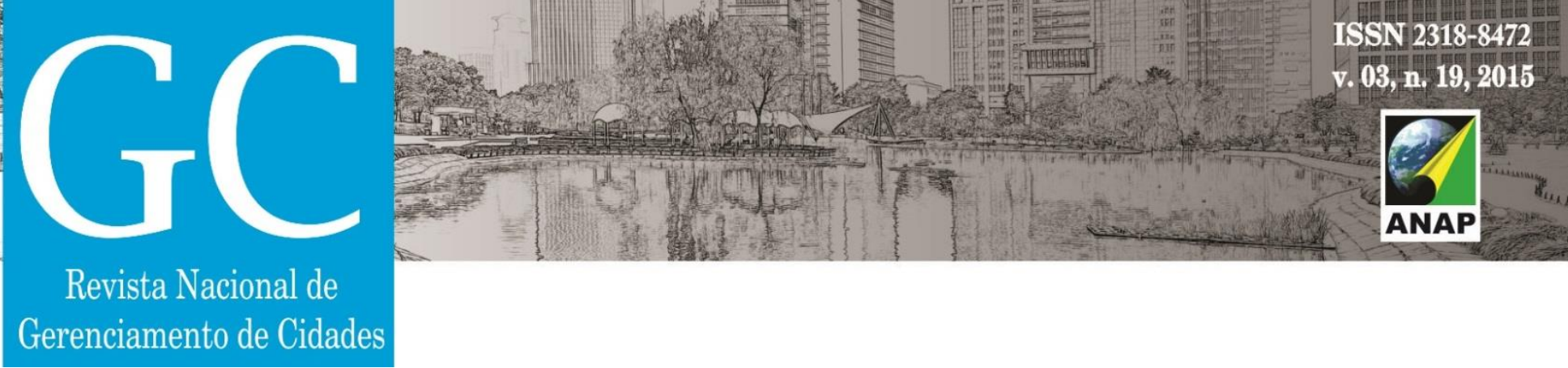

sendo os córregos Macambira e Cascavel de maior vazão, ou seja, em épocas de cheia são os que apresentam maior elevação de seu nível natural de inundação, necessitando assim, de uma maior área permeável de escape para este aumento de vazão temporário.

Analisando mais claramente este Diagnóstico Geral (Figura 1), tem-se o rio Meia Ponte e o ribeirão Anicuns com maiores níveis de problemáticas, mas, como se encontram margeando as áreas periféricas da cidade foram descartadas da escolha para exemplificar este trabalho. Logo, tem-se o córrego Cascavel e o córrego Vaca Brava com problemáticas socioambientais gravemente parecidas além de percorrerem áreas bastante adensadas na cidade. 


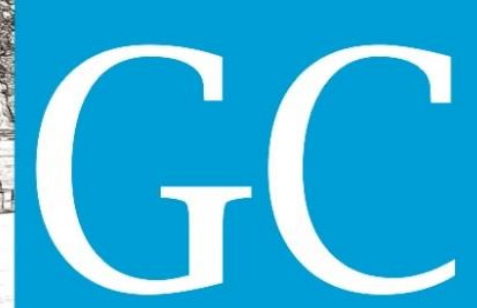

Revista Nacional de

Gerenciamento de Cidades

Figura 1: Diagnóstico ambiental geral de Goiânia

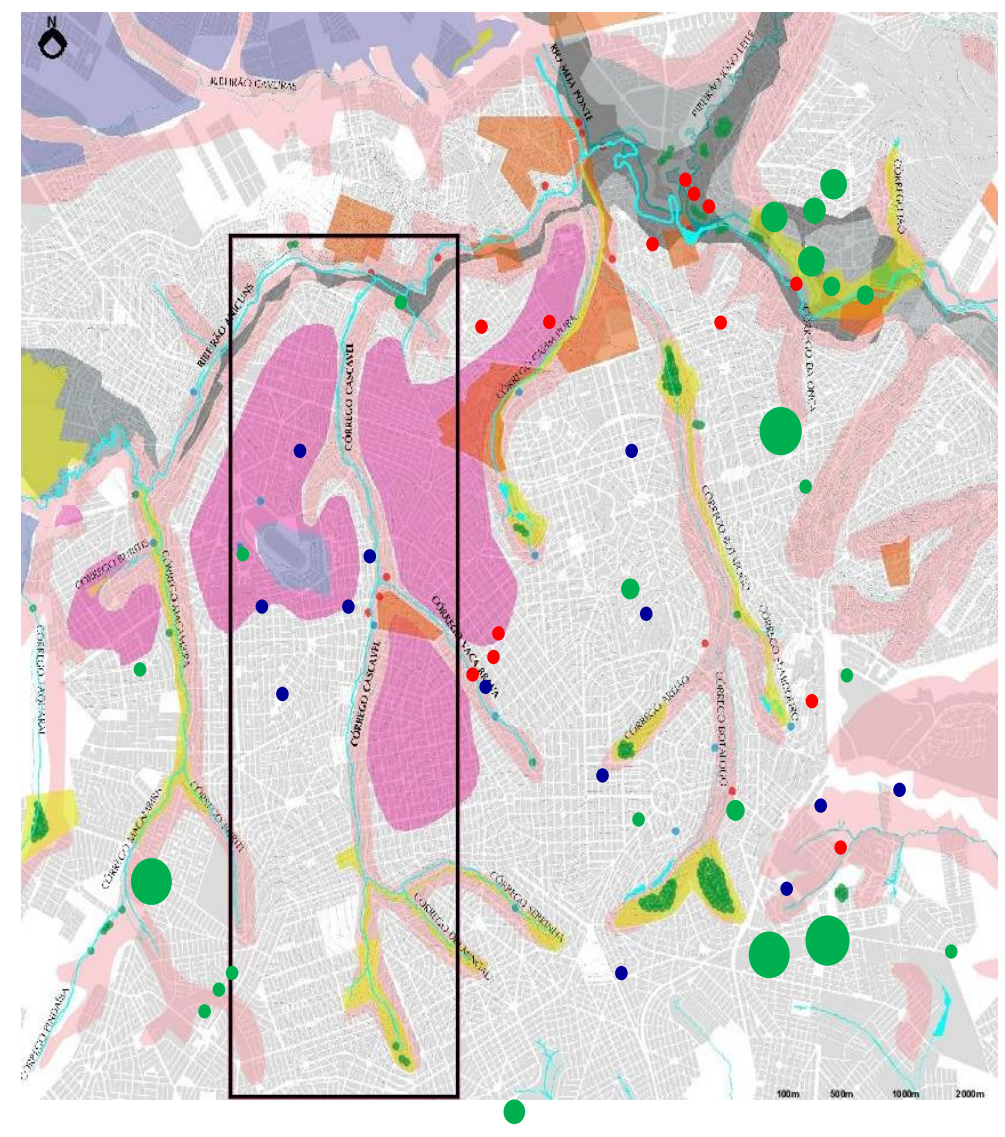

Fundos de vale: Altitudes: 700-900m, declividade acima de $40 \%$ e propensão à erosão em sulcos, ravinas $e$ boçorocas.

Formas tabulares com cobertura de tritico-laterítica: Altitudes: 740-750m, declividade entre 0 a $5 \%$.

Planícies: Altitudes: 690-750m e propensão a inundações periódicas.

Terraços: Altitudes: 700-750m, solos aluviais e inconsistentes.

- Formas Convexas Com Cobertura Detrítico-Laterítica:

Altitudes: $730-800 \mathrm{~m}$, declividade entre 0 a $5 \%$ e propensão a erosões e assoreamento.

- Restantes: Altitude: 700-740m declividade entre 0 a $10 \%$, área com concentração de população e propensão a enxurradas.

Vegetação Nativa

- Área Crítica: Enchente

- Risco de Acidentes em Períodos $\underline{\text { Chuvosos }}$

- Área de Risco: Defesa Civil

U Unidade de Conservação

O Área de Estudo

Cursos D’água

Fonte: GOOGLE, CARTA DE RISCO (1998), ZEE (2008), DEFESA CIVIL (2014) adaptado pela autora, 2014.

Para escolher entre as duas alternativas foi criada uma comparação (Figura 3) a fim de descobrir qual deles teria maior influência no meio urbano. Após esta análise, ficou clara a participação do córrego Cascavel em um cenário urbano mais diversificado socioeconomicamente e mais adensado, sendo este o caso de estudo escolhido. 


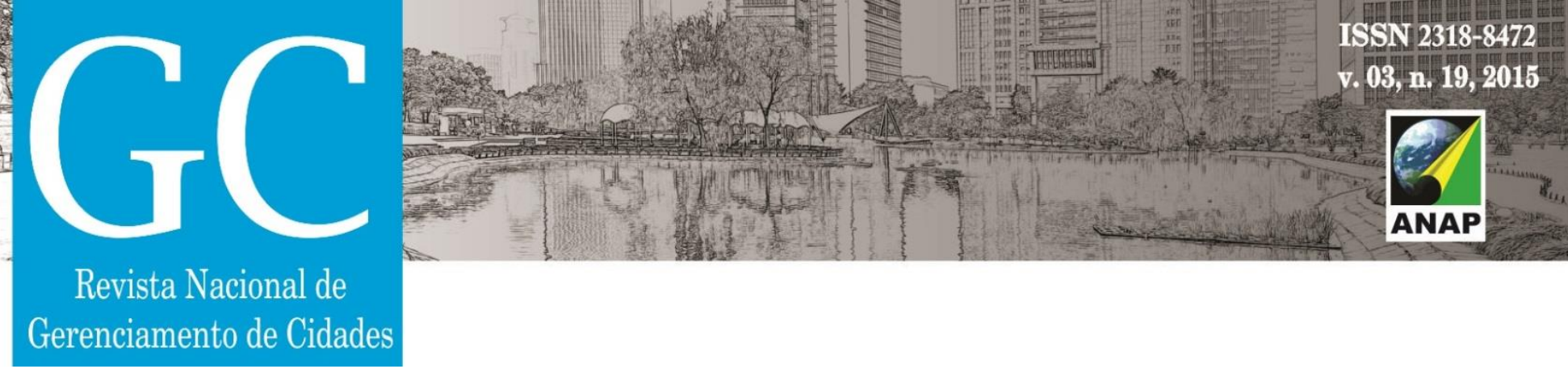

Figura 2: Gráfico com a vazão e duração crítica da mesma em cada curso d'água no meio urbano de Goiânia

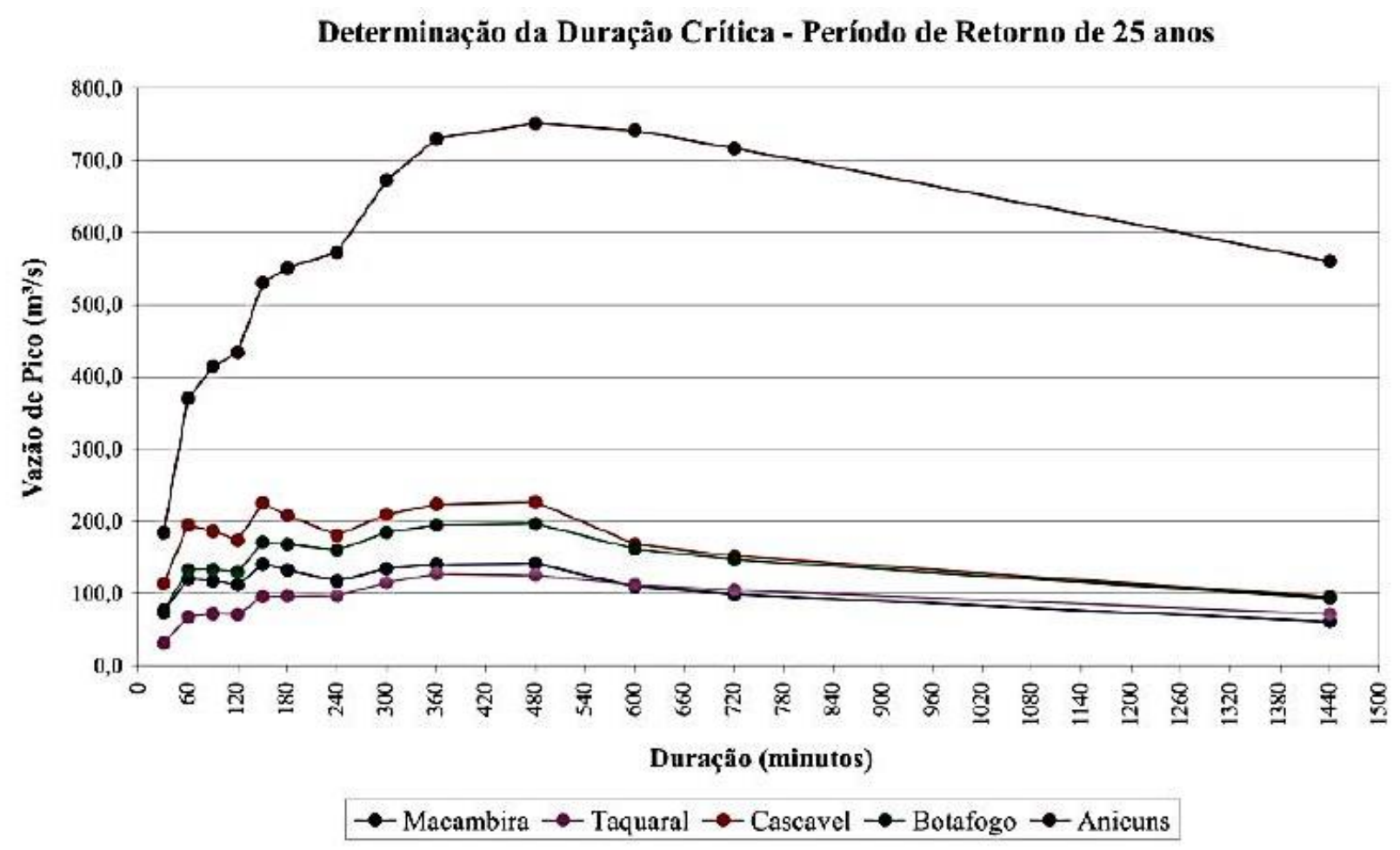

Fonte: PDDGO, 2008.

\section{A REVITALIZAÇÃO DO CÓRREGO - ESTUDO DE NECESSIDADE}

Como foi dito anteriormente, o objetivo deste trabalho é reaproximar o homem da água e seu meio natural, mas esta reaproximação só será possível através de uma total revitalização da relação construída entre o meio natural e urbano ao longo dos anos.

Para isto ser possível, foi necessária a elaboração de três propostas, resultando em três diretrizes de projetos e seus respectivos objetivos, sendo eles: Projeto Urbano - requalificação urbana -, Projeto Paisagístico - apropriação do lugar pela população - e Projeto de Drenagem - segurança e controle de vazão. A Figura 4 sintetiza as diferentes diretrizes, suas particularidades, e os resultados esperados em cada uma das áreas. 


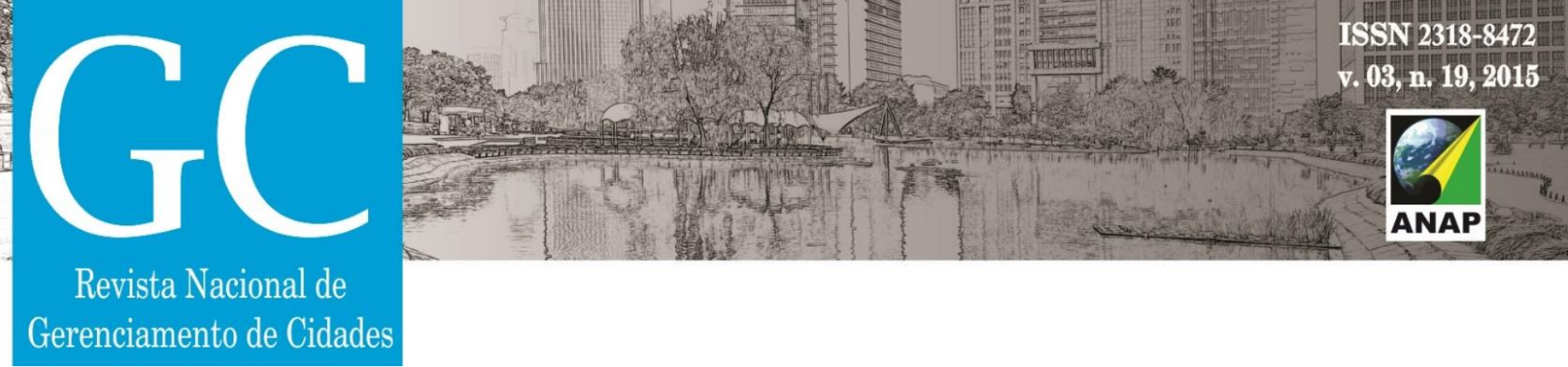

Figura 3: Comparativo de bairros nas margens do córrego Cascavel e córrego Vaca Brava

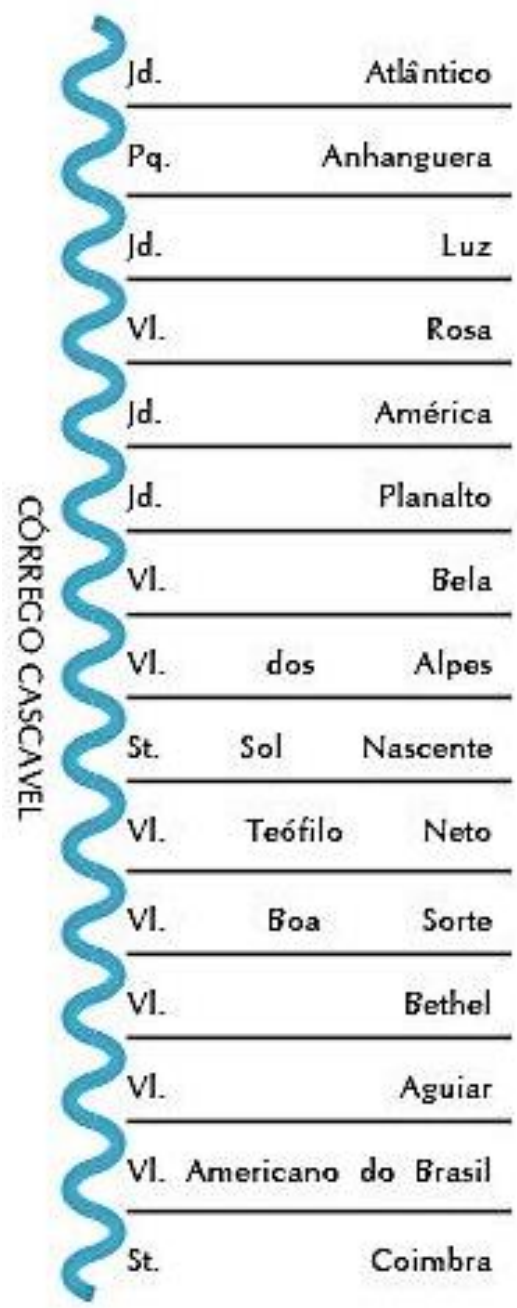

Fonte: PDDGO (2008) adaptado pela autora, 2014.

O Projeto Urbano se consistiu na remodelação urbana consequente da adição da área de preservação permanente do córrego Cascavel defendida pelo Código Florestal, utilizando da desapropriação, defendida pela Lei Federal ํㅜ 3.365, artigo $2^{\circ}$ e $10^{\circ}$, e o consequente remanejamento, das famílias afetadas, para vazios urbanos ou áreas públicas próximas. Nestas novas quadras habitacionais foi proposta uma nova configuração na implantação dos edifícios utilizando $20 \%$ de 


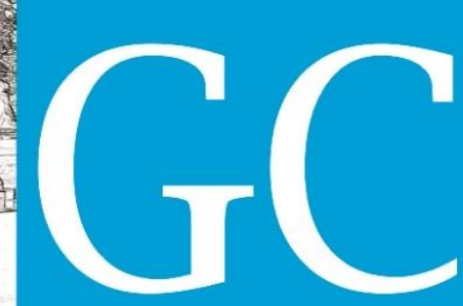

Revista Nacional de

Gerenciamento de Cidades

áreas permeáveis, armazenamento e reuso de águas pluviais a fim de aperfeiçoar o armazenamento da vazão excessiva nas épocas de cheia.

Figura 4: Resumo das diretrizes de revitalização sobre os três projetos propostos no trabalho base deste artigo

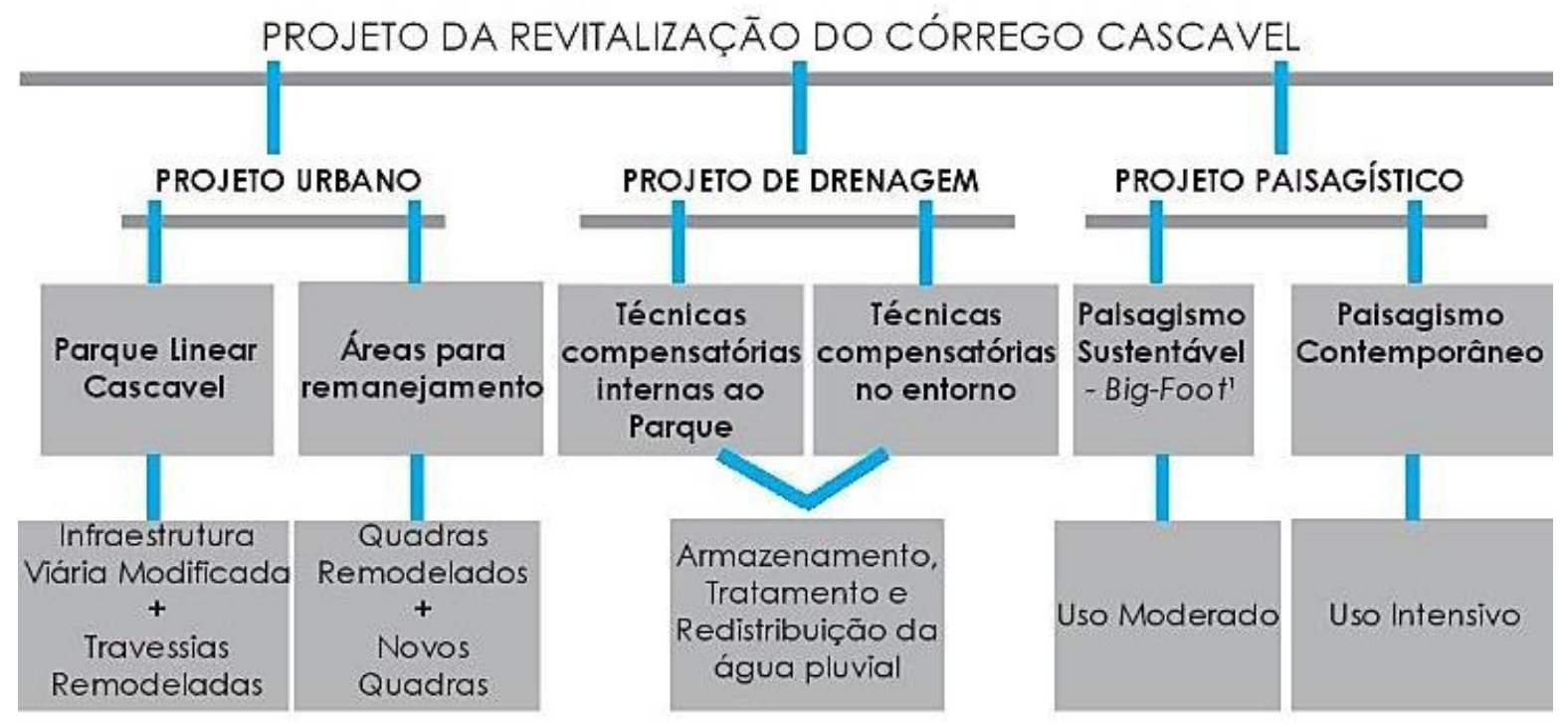

Fonte: AUTORA, 2014.

Quanto ao trecho canalizado do córrego Cascavel foi, primeiramente, defendido a não consolidação do projeto - hoje já aprovado - de canalização da totalidade restante do córrego até sua foz no Ribeirão Anicuns. Por último, foi proposta a reconversão do trecho já canalizado, defendida através da demolição das margens concretadas e a instalação de muro em gabião, permitindo que o solo se recomponha que plantas se desenvolvam neste muro e que a área permeável neste trecho aumente.

Já sabemos que não é mais aceitável pensar em retificar um rio, revestir seu leito vivo com calhas de concreto, e substituir suas margens vegetadas por vias asfaltadas, como uma alternativa de projeto para sua inserção na paisagem urbana. Estas propostas, que tinham como uma de suas bases conceituais a busca do controle das enchentes urbanas, são muito 

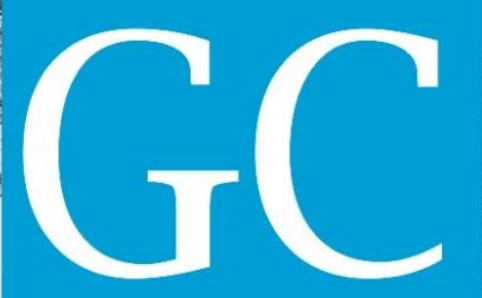

Revista Nacional de

Gerenciamento de Cidades

criticadas não só pela sua fragilidade socioambiental no resultado final do projeto, como também pela pouca eficiência no controle destas mesmas enchentes (COSTA, 2006).

O Projeto Paisagístico Sustentável utiliza vegetação própria para que seja autossuficiente para se manter no clima seco do cerrado sem ter altos gastos com irrigação. Todo o design do projeto paisagístico é definido através das diretrizes lançadas pelas técnicas compensatórias de drenagem, como a presença de bacias de retenção em forma de lagos de contemplação, desníveis e vegetações inundáveis para suprir o excesso de água pluvial em certas estações, trincheiras de detenção de água pluvial ao longo do parque que servem como canteiros diferenciados do paisagismo, entre outras determinantes da drenagem e suas soluções paisagísticas sustentáveis.

\begin{abstract}
Não basta despoluir o rio! Mesmo que ele volte a correr límpido, piscoso, potável, de nada modificará a percepção que a população tem do seu "esgoto a céu aberto". O rio precisa voltar a se incorporar na vida (do paulistano) e, para isso, a única alternativa é reconstituí-lo como espaço de lazer (GORSKI, 2010).
\end{abstract}

Compreender o rio urbano como paisagem é também dar a ele um valor ambiental e cultural que avança na ideia de uma peça de saneamento e drenagem. É reconhecer que o rio urbano e cidade são paisagens mutantes com destinos entrelaçados (COSTA, 2006).

Por último, o Projeto de Drenagem se definiu na implantação das técnicas compensatórias de drenagem no parque linear e seu entorno, a fim de diminuir o impacto direto das chuvas em toda a área de influência da bacia hidrográfica do córrego Cascavel e o pré-dimensionamento e detalhamento das mesmas em um trecho específico da bacia. Este projeto terá seus estudos e resultados expostos neste artigo. 


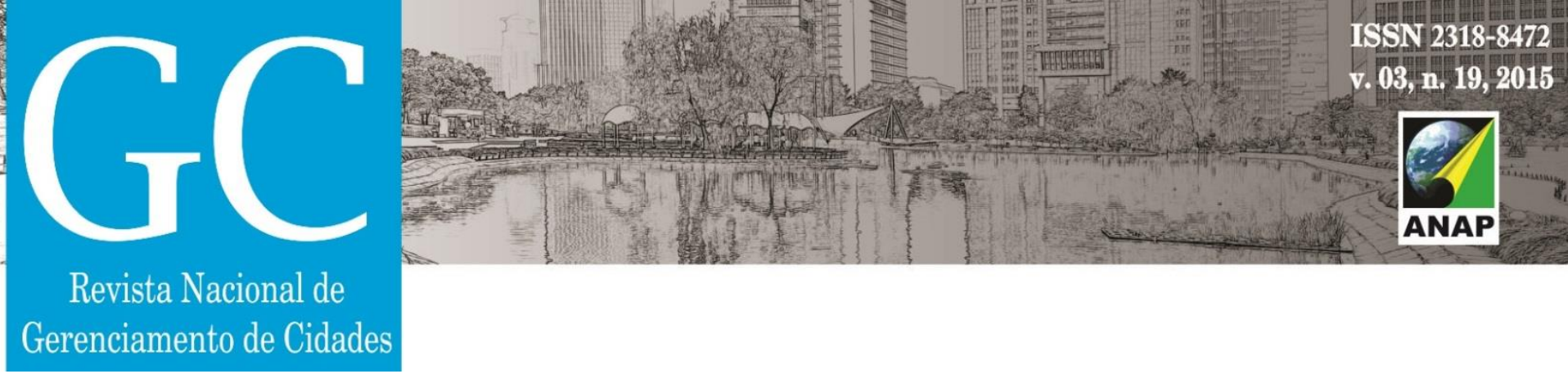

\section{A IMPLEMENTAÇÃO DOS CONCEITOS DE DRENAGEM URBANA SUSTENTÁVEL E TÉCNICAS COMPENSATÓRIAS DE DRENAGEM NO DESENHO URBANO}

O Projeto de Drenagem é de extrema importância para uma real revitalização do córrego, ou seja, para que ao se sentirem seguros em relação às cheias do córrego a população possa se reaproximar e se relacionar com o córrego Cascavel, fazendo ele parte de sua rotina.

Lembrando que, para termos um curso d'água com cheias que não afetam as cidades, que foram erguidas em suas margens, são necessárias duas coisas: Desenvolver os assentamentos urbanos afastados da margem de alagamento natural do córrego e preservar o máximo de áreas permeáveis possíveis, afim de não interferir no volume de água pluvial que o córrego receberá por escoamento das linhas naturais de drenagem - não afetando sua vazão total, logo, não provocando enchentes pela ocupação desenfreada e não sustentável do solo natural.

Infelizmente, os grandes centros urbanos já foram consolidados, em sua maioria, desrespeitando essas duas premissas para um assentamento urbano sustentável, que respeite o ciclo natural do meio ambiente. Assim, o córrego Cascavel, se encontra margeado por uma das ocupações urbanas mais impermeáveis de Goiânia e com suas áreas inundáveis naturais completamente construídas - também impermeabilizadas ou com sua mata natural substituída por gramíneas rasteiras que somente aumentam a velocidade do escoamento das águas pluviais, ou seja, aumenta ainda mais a vazão de água por segundo que será recebida pelo córrego.

Este projeto se dividiu entre duas etapas. A primeira resultou em diretrizes gerais de implantação das Técnicas Compensatórias de Drenagem Urbana internas e externas ao parque linear proposto. A segunda compreendeu-se no detalhamento dos diferentes sistemas de drenagem sustentável em um dos trechos do parque linear, como resultado da vazão hídrica e pluvial que deverá ser contida em cada 


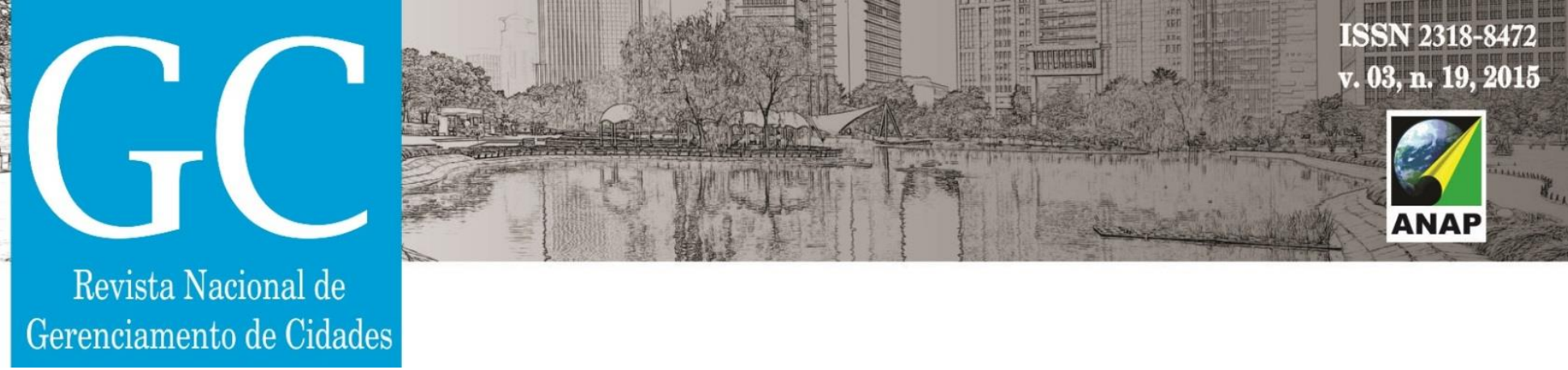

trecho influenciado pela bacia deste córrego e como isto pode ser feito através de mudanças no desenho urbano.

O objetivo da primeira etapa é controlar a vazão recebida pelo córrego Cascavel usando técnicas compensatórias de drenagem urbana que funcionem como prevenção, para que enchentes não ocorram, e não como tentativas de controle - remediação - das mesmas como fazem as técnicas tradicionais de Drenagem Urbana.

Para determinar quais técnicas compensatórias de drenagem serão usadas, e onde serão implantadas, é preciso seguir as seguintes etapas:

\section{Determinar a área de Influência da bacia do córrego Cascavel e as linhas de drenagem natural do terreno (Figura 5):}

Esta área de influência pode ser encontrada no Plano Diretor de Drenagem Urbana e as linhas naturais de drenagem podem ser observadas através da declividade da topografia. Vale ressaltar que com a impermeabilização intensa da região essas linhas naturais de drenagem ficam extremamente sobrecarregadas 0 que resulta nas enchentes em suas imediações. Assim, podem-se observar quais são as áreas disponíveis adjacentes a estas declividades para que já se compreenda quais técnicas podem ser implantadas de forma mais incisiva nestas regiões de risco. 


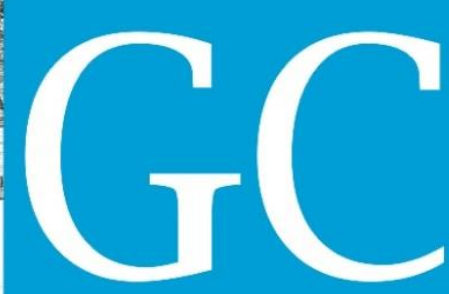

Revista Nacional de

Gerenciamento de Cidades

Figura 5: Área de influência da bacia do córrego Cascavel e suas linhas naturais de drenagem
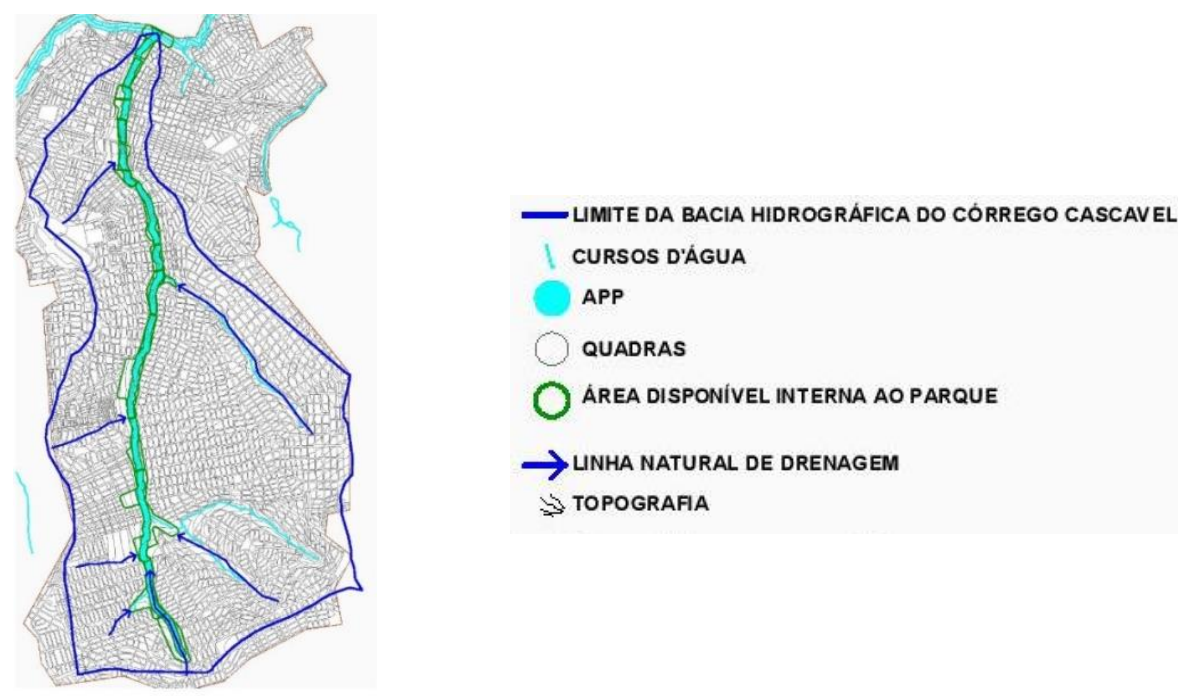

Fonte: PDDGO adaptado pela autora, 2008.

\section{Escolha das técnicas compensatórias de drenagem para a bacia do córrego Cascavel:}

Para definir quais entre as já conhecidas técnicas compensatórias de drenagem seriam apropriadas para a área da bacia do córrego Cascavel foram utilizadas as metodologias de análise de BAPTISTA, NASCIMENTO e BARRAUD (2011, p. 41-60). Após uma análise inicial, foi elaborado um quadro síntese (Tabela 1) baseado nas metodologias apresentadas por USEPA (1993), DayWater (2003) e Azzout (1994) presentes em BAPTISTA, NASCIMENTO e BARRAUD (2011, p. 55). Assim, podem-se observar quais técnicas eram mais restritivas para a área em estudo e quais seriam mais adequadas para a mesma (Tabela 2).

Ambas as tabelas foram divididas entre áreas externas e internas ao Parque Linear, pois compreendem solos e declividades diferentes, logo, recebem diferentes 


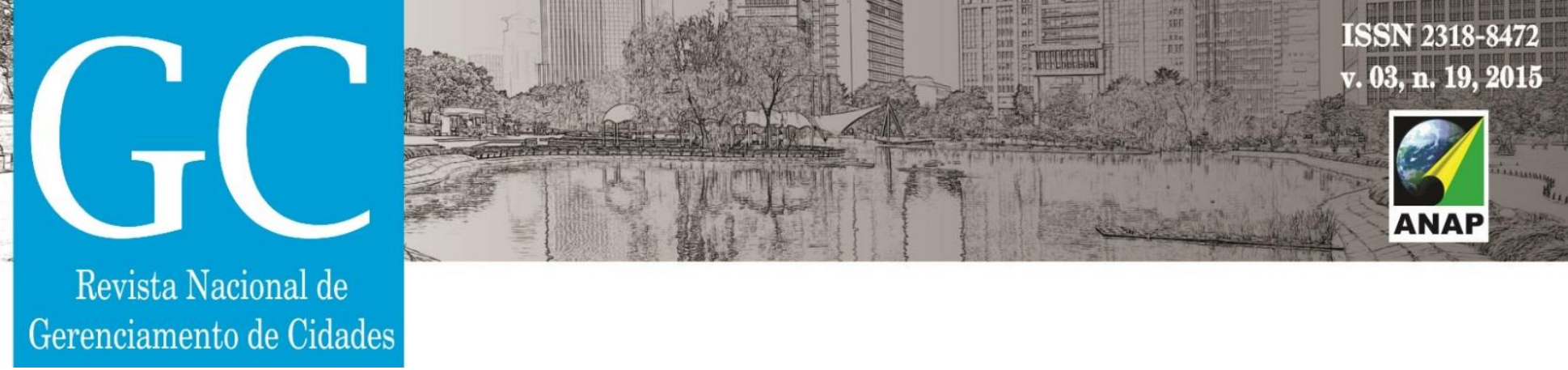

Vale lembrar que áreas extremamente urbanizadas podem obter um $\mathrm{CN}$ de 90-100 e áreas pré-urbanizadas possuem um CN de 15, este trecho foi finalizado, após as propostas de novas áreas permeáveis, com um CN de 69, ou seja, ainda longe do ideal $\mathrm{CN}$ de 55, que se busca em áreas urbanas já consolidadas, mas com algum equilíbrio, e que foi utilizado na Tabela 4 de Estudos Hidrológicos para o cálculo de vazão excedente da região. Este $\mathrm{CN}$ de 55 tem sido exigido para a aprovação de novos loteamentos do Distrito Federal como o Residencial Santa Bárbara (ALMEIDA, 2014).

Tabela 1: Importância relativa de restrições à implantação e operação de técnicas compensatórias de drenagem

\begin{tabular}{|c|c|c|c|c|c|c|c|c|c|c|}
\hline \multirow{3}{*}{ Técnicas } & \multicolumn{10}{|c|}{ RESTRIÇÕES A IMPIANTAÇÃO E OPERAÇÃO DE TÉCNICAS } \\
\hline & \multicolumn{2}{|c|}{ Permeabilidode doSolo } & \multicolumn{2}{|c|}{ Declividade } & \multicolumn{2}{|c|}{ Proximidade do Lençol } & \multicolumn{2}{|c|}{ Proximidade do Leito Rochoso } & \multicolumn{2}{|c|}{ Restriçঠ̃es ao Uso de Solc } \\
\hline & $\begin{array}{l}\text { Interna oo } \\
\text { Parque }\end{array}$ & $\begin{array}{l}\text { Externa oo } \\
\text { Porque }\end{array}$ & $\begin{array}{c}\text { Interno oo } \\
\text { Parque }\end{array}$ & $\begin{array}{l}\text { Externa co } \\
\text { Parque }\end{array}$ & $\begin{array}{l}\text { Interno ao } \\
\text { Parque }\end{array}$ & $\begin{array}{c}\text { Externa oo } \\
\text { Parque }\end{array}$ & $\begin{array}{l}\text { Interna coo } \\
\text { Parque }\end{array}$ & $\begin{array}{l}\text { Externa coo } \\
\text { Parque }\end{array}$ & $\begin{array}{l}\text { Interno co } \\
\text { Parque }\end{array}$ & $\begin{array}{c}\text { Externa oo } \\
\text { Parque }\end{array}$ \\
\hline Bacia de Detençăo & * & * & * & * & * & * & ** & ** & *** & *** \\
\hline Bacia de Infiltração & $* * *$ & $* * *$ & * & * & $* * *$ & $* * *$ & $* * *$ & $* * *$ & $* * *$ & $* * *$ \\
\hline $\begin{array}{l}\text { Valos e Valetos de } \\
\text { Detençáo }\end{array}$ & * & * & ** & ** & * & * & ** & ** & ** & ** \\
\hline $\begin{array}{l}\text { Valos e Valetos de } \\
\text { Infiltraçāo }\end{array}$ & *** & *** & $* * *$ & *** & *** & *** & $* * *$ & $* * *$ & ** & ** \\
\hline Povimentos Porosos & ** & ** & *** & *** & ** & ** & * & * & * & * \\
\hline $\begin{array}{l}\text { Revestimentos } \\
\text { Permeáveis }\end{array}$ & ** & ** & **** & $* * *$ & ** & ** & * & * & * & * \\
\hline Trincheiras de Detenção & * & * & ** & ** & ** & ** & ** & ** & $* *$ & ** \\
\hline Irincheiras de Infiltração & $* * *$ & $* * *$ & $* * *$ & $* * *$ & $* * *$ & $* * *$ & $* * *$ & *** & $* *$ & ** \\
\hline Poços de Infiltração & $* * *$ & *** & * & * & $* * *$ & $* * *$ & $* * *$ & **** & ** & ** \\
\hline Telhados Armazenadores & $*$ & * & * & * & $*$ & * & * & * & $*$ & * \\
\hline Reservatórios Individuais & $*$ & * & $*$ & * & $* *$ & ** & ** & ** & * & * \\
\hline
\end{tabular}

Fonte: BAPTISTA, NASCIMENTO E BARRAUD, adaptado pela autora, 2011. 


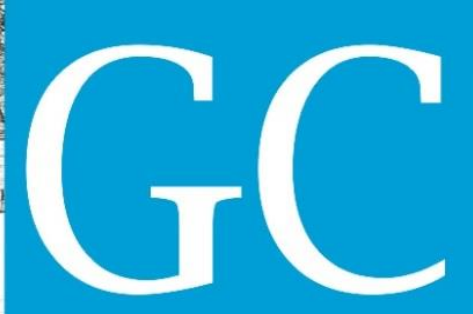

Revista Nacional de

Gerenciamento de Cidades

Tabela 2: Técnicas compensatórias de drenagem na área de influência da bacia do córrego Cascavel internas e externas ao Parque Linear

\begin{tabular}{|c|c|}
\hline \multicolumn{2}{|c|}{ APLICÁVEIS } \\
\hline Interna ao Parque & $\begin{array}{c}\text { Externa ao } \\
\text { Parque }\end{array}$ \\
\hline Bacia de Detenção & $\begin{array}{l}\text { Bacia de } \\
\text { Detenção }\end{array}$ \\
\hline $\begin{array}{c}\text { Valas e Valetas de } \\
\text { Detenção }\end{array}$ & $\begin{array}{l}\text { Bacia de } \\
\text { Infiltração }\end{array}$ \\
\hline Trincheiras de Detenção & $\begin{array}{l}\text { Valas e Valetas } \\
\text { de Detenção }\end{array}$ \\
\hline Bacia de Infiltração & $\begin{array}{l}\text { Valas e Valetas } \\
\text { de Infiltração }\end{array}$ \\
\hline Pavimentos Porosos & $\begin{array}{l}\text { Pavimentos } \\
\text { Porosos }\end{array}$ \\
\hline & $\begin{array}{l}\text { Revestimentos } \\
\text { Permeáveis }\end{array}$ \\
\hline & $\begin{array}{l}\text { Trincheiras de } \\
\text { Detenção }\end{array}$ \\
\hline & $\begin{array}{l}\text { Trincheiras de } \\
\text { Infiltraçāo }\end{array}$ \\
\hline & $\begin{array}{l}\text { Poços de } \\
\text { Infiltração }\end{array}$ \\
\hline & $\begin{array}{c}\text { Tehados } \\
\text { Armazenadores }\end{array}$ \\
\hline & $\begin{array}{l}\text { Reservatórios } \\
\text { Individuais }\end{array}$ \\
\hline
\end{tabular}

Fonte: AUTORA, 2014.

Figura 7: Delimitação e cálculos gerais da área para o cálculo de vazão e pré-dimensionamento detalhado das técnicas compensatórias de drenagem

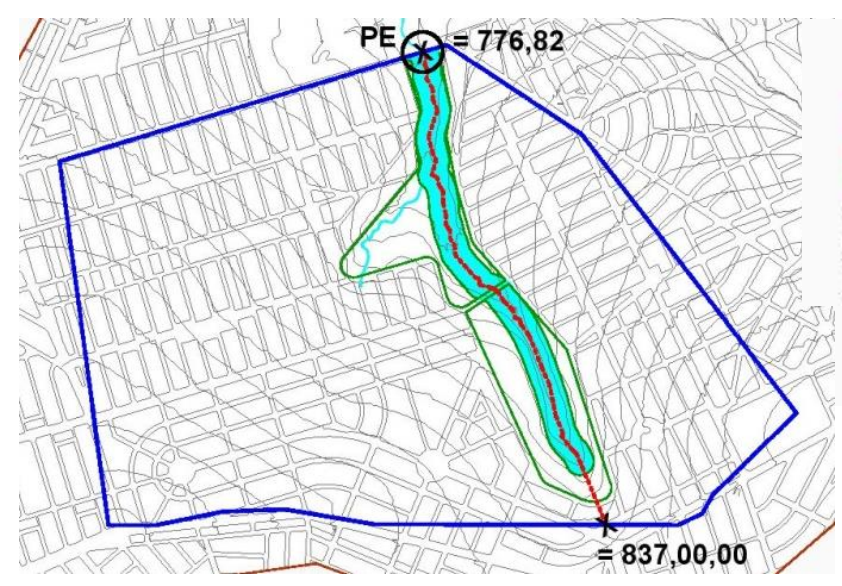



DESNIVEL DAS EXTREMIDADES DA EXTENSÃO DO TALVEGUE $=60,18 \mathrm{~m}$

Fonte: AUTORA orientada por ALMEIDA, 2014. 


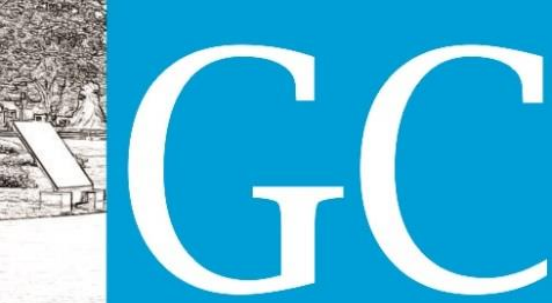

Revista Nacional de

Gerenciamento de Cidades

Figura 6: Síntese da implantação das técnicas compensatórias de drenagem urbana na área da bacia do córrego Cascavel escolhidas através da metodologia de USEPA (1993), DAYWATER (2003) e AZZOUT (1994)
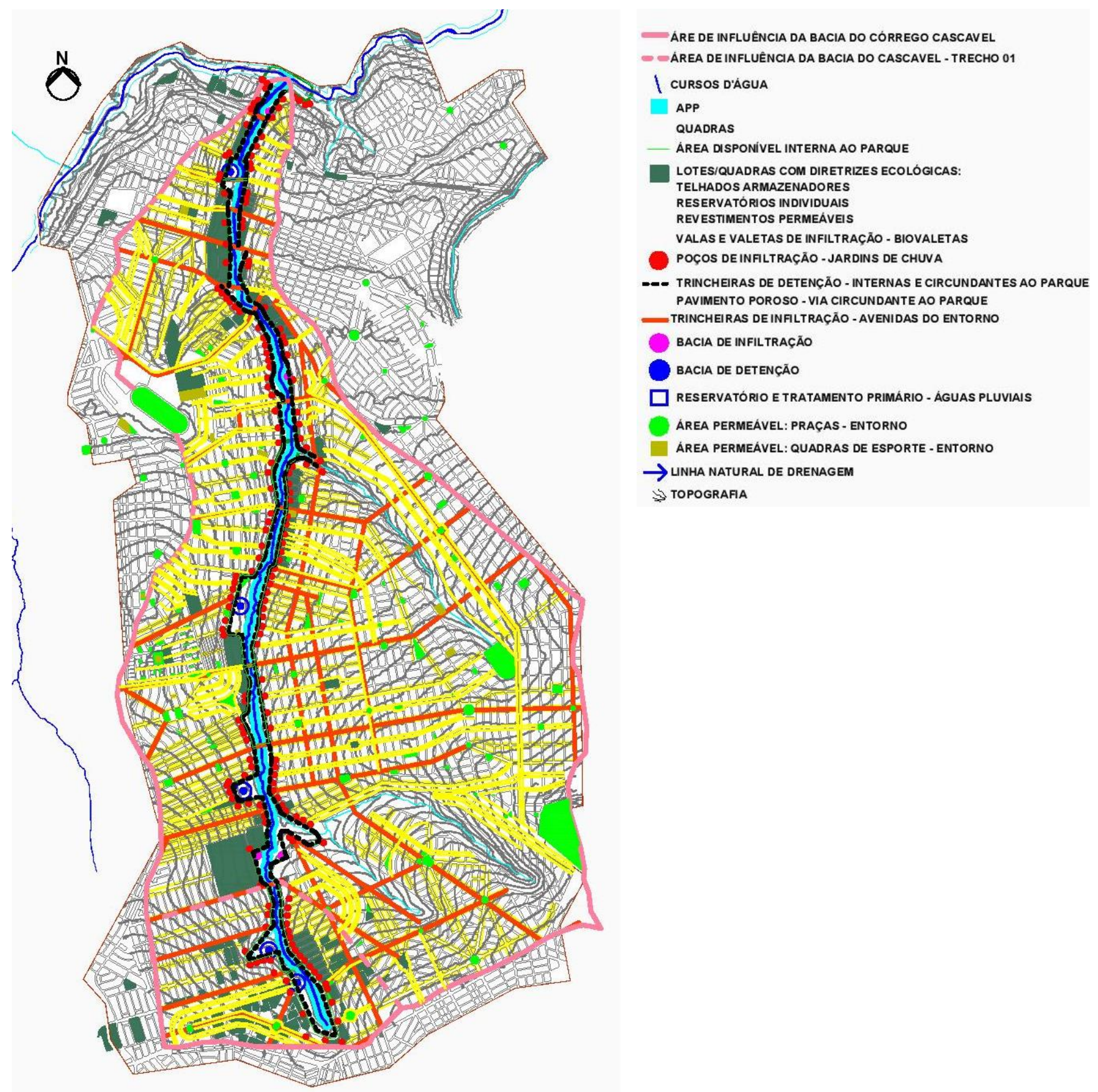

Fonte: AUTORA, 2014. 


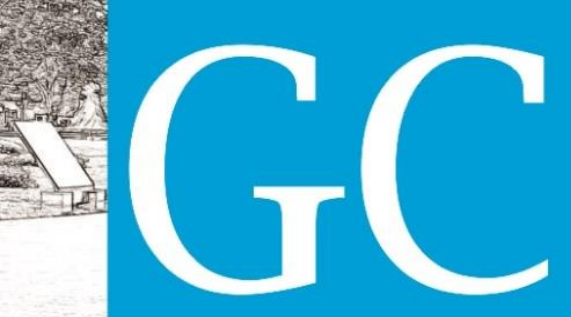

Revista Nacional de

Gerenciamento de Cidades

Figura 8: Análise das áreas impermeáveis

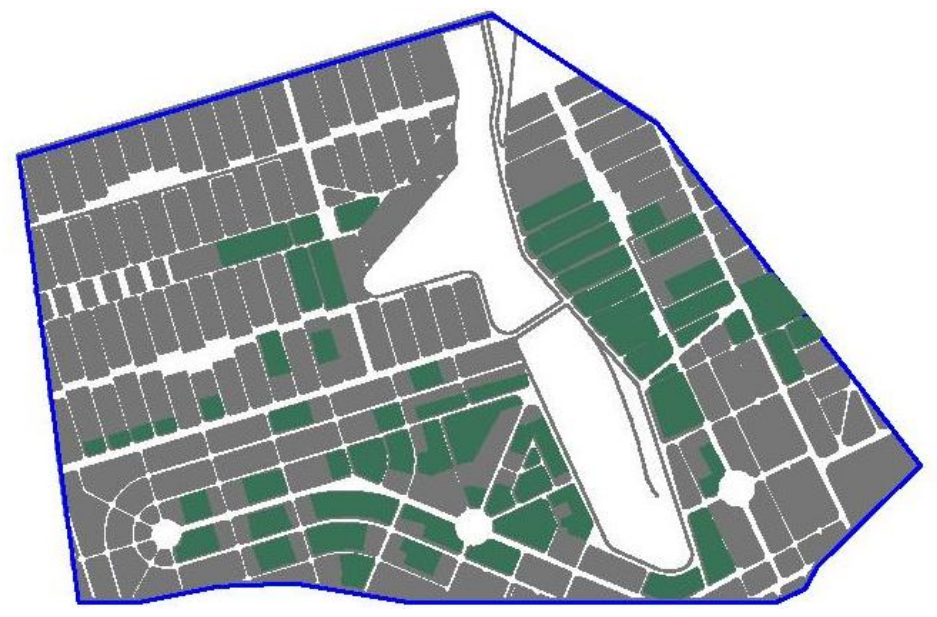

QUADRAS NOVAS E REMODELADAS $=570.816,56 \mathrm{~m}^{2}$

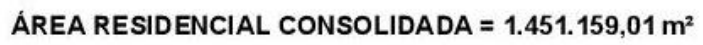

VIAS $=1.790 .728,70 \mathrm{~m}^{2}$

ÁREA DE CONTRIBUIÇÃO $=3.812 .704,39 \mathrm{~m}^{2}$

Fonte: AUTORA orientada por ALMEIDA, 2014.

Figura 9: Análise das áreas permeáveis após propostas gerais das técnicas compensatórias na bacia do Cascavel

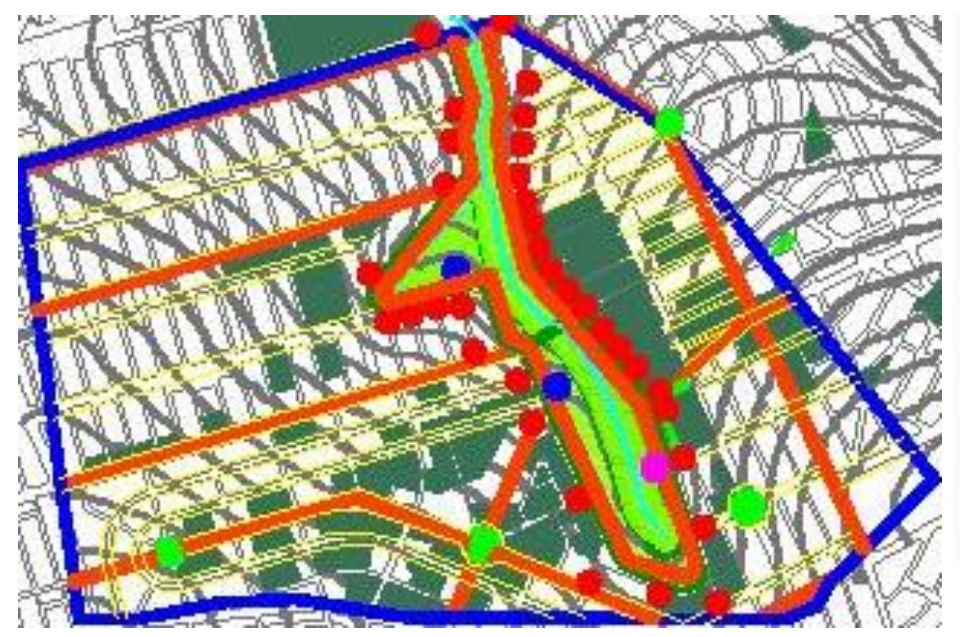

$P A R Q U E+A P P=529.812,52 \mathrm{~m}^{2}$

VALETAS DE INFILTRAÇÃO - BIOVALETAS $=416.397,80 \mathrm{~m}^{2}$

- TRINCHEIRAS DE INFILTRAÇÃO $=13843,87 \mathrm{~m}^{2}$

20\% DE ÁREA PERMEÁVEL DAS QUADRAS NOVAS E REMODELADAS $=114.163,25 \mathrm{~m}^{2}$

PRAÇAS $\mid$ ÁREAS VERDES $=23.510,84 \mathrm{~m}^{2}$

POÇOS DE INFILTRAÇÃO - JARDINS DE CHUVA $=340,00 \mathrm{~m}^{2}$

ÁREA DE CONTRIBUIÇÃO $=3.812 .704,39 \mathrm{~m}^{2}$

bacia de detenção

BACIA DE INFILTRAÇÃo

Fonte: AUTORA orientada por ALMEIDA, 2014. 


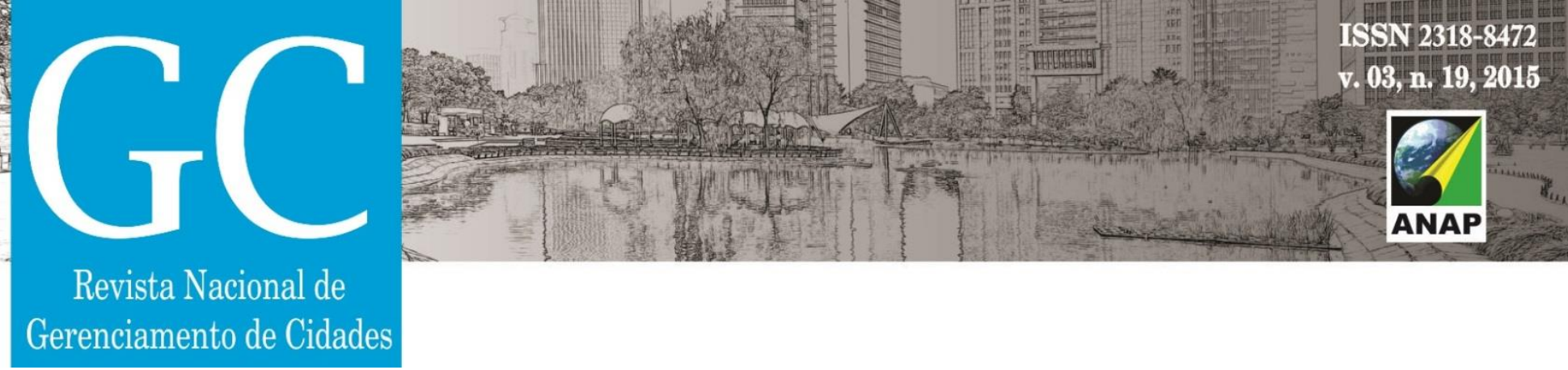

Tabela 3: Cálculo do coeficiente de impermeabilização final da área

\begin{tabular}{|c|c|c|c|c|c|}
\hline \multicolumn{6}{|c|}{ COMPOSIÇĀO DE ÁREA "CN" } \\
\hline & $m^{2}$ & $\mathrm{~km}^{2}$ & CN adotado & $\%$ & \\
\hline Área total & $3.812 .704,0$ & 3,8127 & - & - & - \\
\hline Área permeável & $1.098 .068,3$ & 1,0981 & 30 & $29 \%$ & - \\
\hline Área residencial (mplantado) & $1.451 .159,0$ & 1,4512 & 85 & $38 \%$ & 32,35 \\
\hline Vias & $1,790.728,7$ & 1.7907 & 85 & $47 \%$ & 39,92 \\
\hline Área de impermeável & $-527.252,0$ & & 85 & $-14 \%$ & $-11,75$ \\
\hline
\end{tabular}

Solo $100 \%$ Impermeabilizado: $\mathrm{C}=100$

Áreas pré-urbanizadas: $\mathrm{C}=15$

Áreas Urbanizadas: $\mathrm{C}=80 / 90$

Fonte: ALMEIDA adaptado pela autora, 2014.

\section{RESULTADOS}

\section{CÁLCULO DA VAZÃO DA ÁGUA PLUVIAL}

Todos os dados analisados anteriormente foram sintetizados na tabela de Estudos Hidrológicos |Hidrograma unitário - cedida por ALMEIDA, 2014 - onde se pode calcular a vazão total de águas pluviais que serão recebidas neste trecho de detalhamento interior a bacia do Cascavel. Esta vazão, calculado em $\mathrm{m}^{3} / \mathrm{s}$, é transformada para um total de 30 minutos do pico chuvoso mais rigoroso da região. Desta forma descobre-se qual é o volume total de água que deve ser permeado ou retido para que não haja sobrecarga deste trecho na bacia do Cascavel, evitando assim as enchentes do córrego (Tabela 4). 

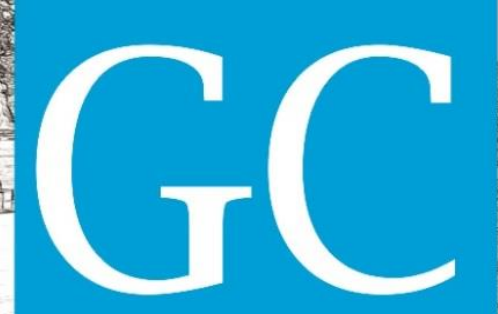

Revista Nacional de

Gerenciamento de Cidades

Tabela 4: Cálculo da vazão total de água pluvial recebida pela bacia e volume total a ser retido nas futuras intervenções

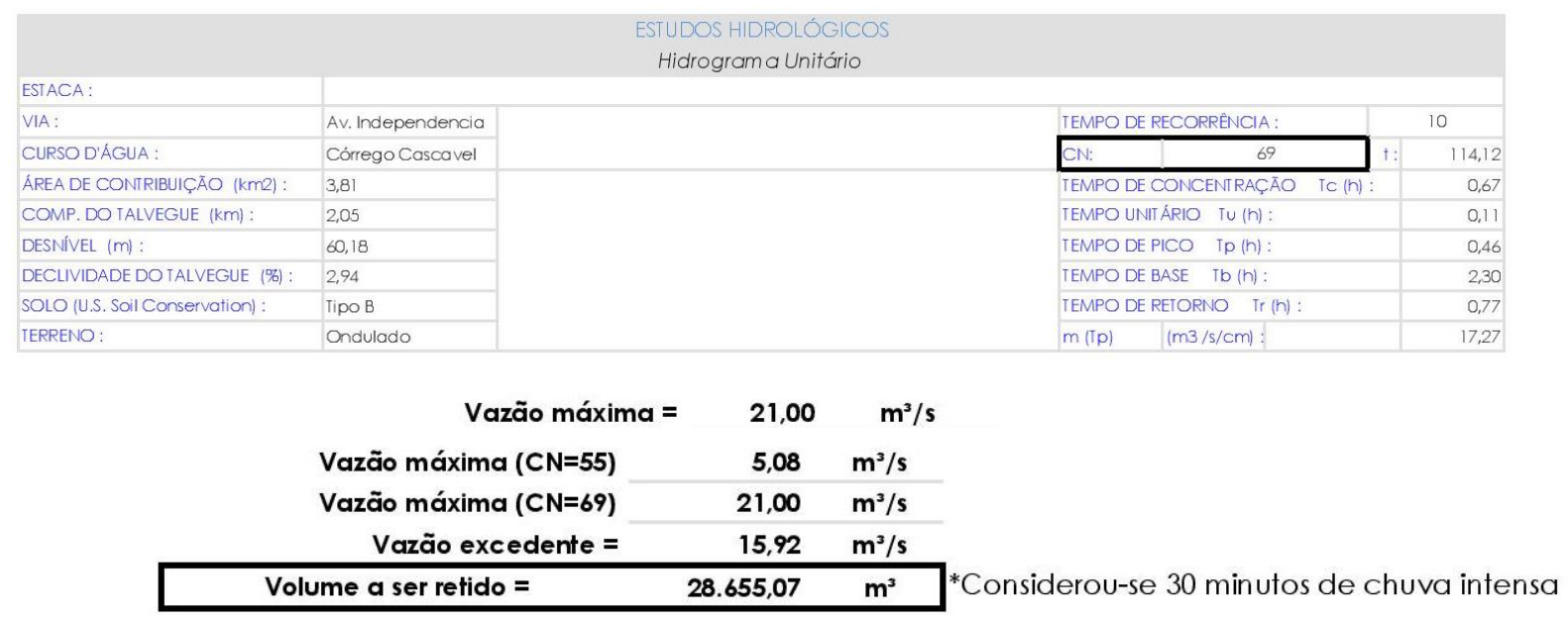

Fonte: ALMEIDA adaptado pela autora, 2014.

A partir deste volume pode-se calcular a dimensão de cada técnica compensatória de drenagem urbana necessária para retê-lo (Tabela 05) assim como o volume total para armazenamento da vazão excedente assim como um limite de reserva de $3.719,15 \mathrm{~m}^{3}$.

Tabela 5: Cálculo de pré-dimensionamento e capacidade, em volume, total necessária para cada técnica compensatória de drenagem urbana

\begin{tabular}{|c|c|c|c|}
\hline \multicolumn{4}{|c|}{ Volume a ser retido $\mathbf{2 8 . 6 5 5 , 0 7}$} \\
\hline & Área $\left(\mathrm{m}^{2}\right)$ & Volume $\left(\mathrm{m}^{3}\right)$ & Observação \\
\hline $\begin{array}{c}\text { Bacia de } \\
\text { Detenção }\end{array}$ & 15298,56 & 20625 & Forma prismática \\
\hline $\begin{array}{c}\text { Jardim de } \\
\text { Chuva }\end{array}$ & 340 & 238 & $70 \%$ da capacidade bruta \\
\hline $\begin{array}{c}\text { Trincheira de } \\
\text { Infiltração }\end{array}$ & 13843,87 & 9690,7 & $70 \%$ da capacidade bruta \\
\hline $\begin{array}{c}\text { Trincheira de } \\
\text { Detenção }\end{array}$ & 2600,74 & 1820,52 & \\
\hline $\begin{array}{c}\text { Total } \\
\text { Reserva }\end{array}$ & - & $\mathbf{3 2 3 7 4 , 2 2}$ \\
\hline
\end{tabular}

Fonte: AUTORA orientada por ALMEIDA, 2014. 


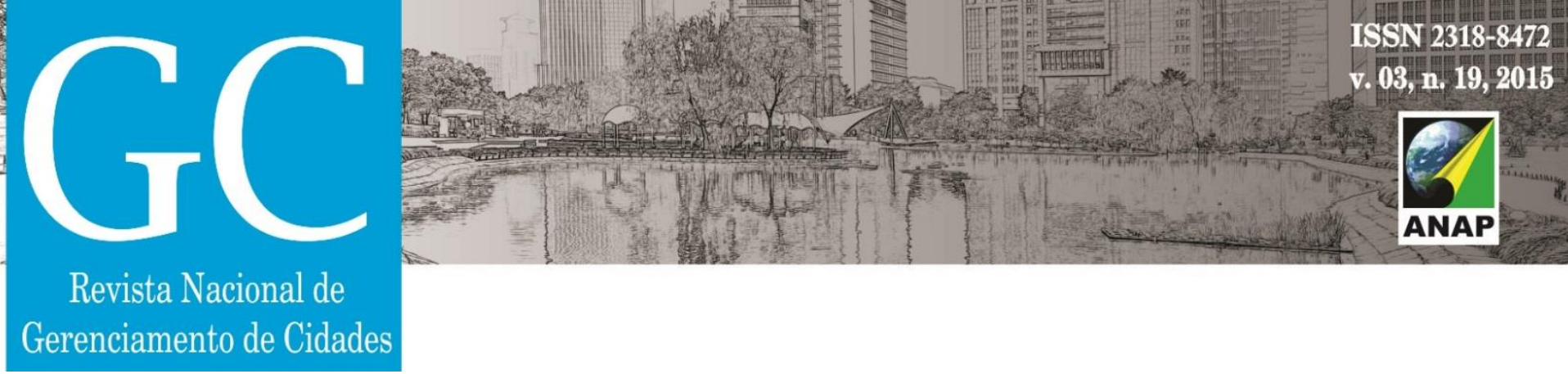

CONCLUSÃO

Neste artigo, foi possível provar a capacidade de se reverter o quadro de desastres naturais e a consequente ruptura entre o relacionamento do homem com os cursos d'água, mesmo em centros urbanos consolidados, ou seja, onde o nível de permeabilidade do solo é praticamente nulo mantendo um quadro de incapacidade natural da bacia hidrográfica em absorver a grande vazão da água pluvial.

Isto foi possível através do cálculo exato da vazão de água pluvial atual em áreas urbanas consolidadas, da capacidade real do curso d'água em absorver certo volume e o volume excedente - que se traduz nas enchentes urbanas recorrentes. Sabendo cada volume exato foi possível pré-dimensionar as Técnicas Compensatórias de Drenagem Urbana, a fim de determinar um desenho urbano sensível à água que tem real capacidade em absorver e armazenar o volume de água pluvial excedente. Assim, evitam-se as enchentes e desabamentos além de renovar a segurança do homem para com o curso d'água através do equilíbrio entre expansão urbana e preservação ambiental.

\section{REFERÊNCIAS}

ALMEIDA, Fernanda. Mestranda em Engenharia de Recursos Hídricos, MBA em Perícia e Auditoria Ambiental e Tecnóloga em Gestão Ambiental pelo CEFET-GO, integrante da equipe da empresa BASITEC - projetos de drenagem urbana - em entrevista. Goiânia, 2014.

AMMA, Agência Municipal do Meio Ambiente. Diagnóstico Ambiental da Bacia Hidrográfica do Córrego Cascavel. Goiânia, 2008.

BARATTO, Romullo. Oito exemplos de que é possível despoluir os rios urbanos. Disponível em <http://www.archdaily.com.br/168964/oito-exemplos-de-que-e-possivel-despoluir-os-rios-urbanos>. Acesso em maio de 2014.

BAPTISTA, Márcio; NASCIMENTO, Nilo; BARRAUD, Sylvie. Técnicas compensatórias em drenagem urbana. Porto Alegre: $A B R H, 2011$.

CAMARA, Eric Brucher. Despoluição do Tâmisa. Disponível em $<$ http://www.bbc.co.uk/portuguese/noticias/story/2004/01/040121_tamisaebc.shtml> Acesso em maio de 2014.

DEFESA CIVIL. Relatório das áreas de risco. Goiânia, 2014. 


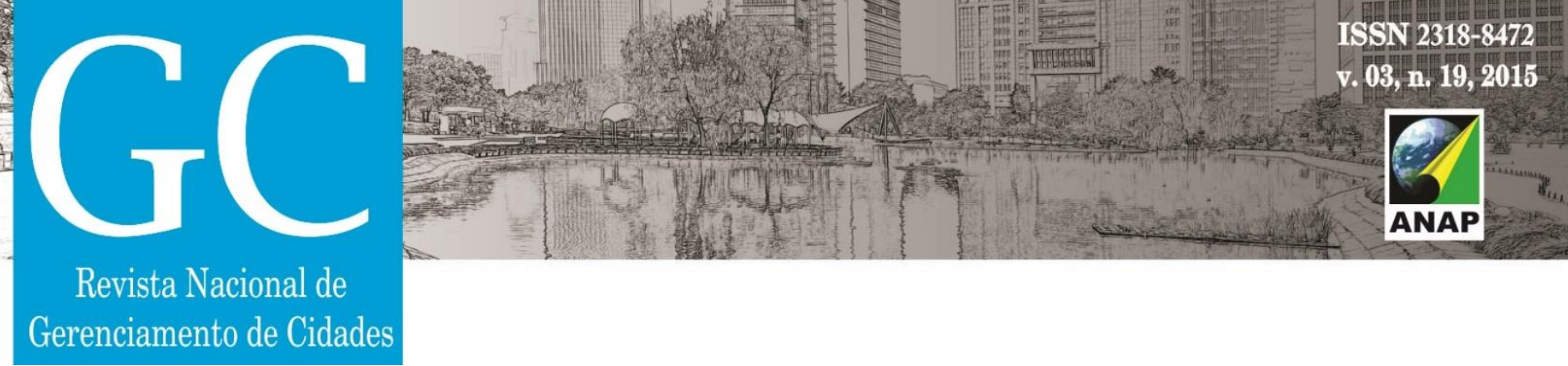

DE JONGH, 1999; MAPPIN, 2000 apud GORSKI, Maria Cecília Barbieri. Rios e Cidades: Ruptura e Reconciliação. São Paulo: SENAC, 2010.

FERRAZ, Caio Silva. Entre Rios. São Paulo: Trabalho de Conclusão - SENAC, 2009.

FOLHA. Seca fora de época faz 93 cidades cortarem a água. Disponível em <http://www1.folha.uol.com.br/cotidiano/2015/01/1573336-seca-fora-de-epoca-no-pais-faz-93cidades-cortarem-a-agua.shtml> Acesso em março de 2015.

GHEL, Jan. Cidades para pessoas. São Paulo: Perspectiva S.A., 2014.

GORSKI, Maria Cecília Barbieri. Rios e Cidades: Ruptura e Reconciliação. São Paulo: Editora SENAC, 2010.

JACOBS, Jane. Morte e Vida das Grandes Cidades. São Paulo: WMF Martins Fontes, 2011.

MOSTAFAVI, Mohsen; DOHERTY, Gareth. Ecological urbanism. Harvard University: Lars Müller Publishers, 2010.

RIBEIRO, Maria Eliana Jubé. Goiânia: os planos, a cidade e o sistema de áreas verdes. Goiânia: Universidade Católica de Goiás, 2004.

SANTOS, Rozely Ferreira. Planejamento Ambiental teoria e prática. São Paulo: Oficina de Textos, 2007.

STORMWATER COMMITTEE. Urban Stormwater: Best practice environmental management guidelines. Collingwood, Austrália: CSIRO, 2006.

SURVIO. Disponível em <https://www.survio.com/survey/d/Y3Q5V9X9D9X9I1K9Y> 